\title{
Suplementasi Mineral Lokal untuk Perbaikan Nutrisi dan Reproduksi Sapi Peranakan Simmental Dara pada Peternakan Rakyat di Jorong Sibaladuang, Kabupaten Limapuluh Kota
}

\section{(Local Mineral Supplementation for Better Nutrition and Reproduction of Simmental-Cross Heifers Raised by Smallholders in Sibaladuang Village, Limapuluh Kota District)}

\author{
Khalil $^{1 *}$, Andri' ${ }^{2}$, Zaituni Udin ${ }^{3}$ \\ ${ }^{1}$ Bagian Ilmu Nutrisi dan Teknologi Pakan, Fakultas Peternakan Universitas Andalas, Kampus II Payakumbuh, \\ Jl. Rasuna Said, Kelurahan Kubu Gadang, PayakumbuhBarat, Sumatera Barat 26226. \\ 2 Bagian Bisnis dan Pembangunan Peternakan, Fakultas Peternakan Universitas Andalas, Kampus II Payakumbuh, Jl. Rasuna \\ Said, Kelurahan Kubu Gadang, PayakumbuhBarat, Sumatera Barat 26226. \\ 3 Bagian Teknologi Produksi Ternak, Fakultas Peternakan Universitas Andalas, Kampus II Payakumbuh, \\ Jl. Rasuna Said, Kelurahan Kubu Gadang, PayakumbuhBarat, Sumatera Barat 26226. \\ *Penulis Korespondensi: khalil@ansci.unand.ac.id \\ Diterima Maret 2019/Disetujui Agustus 2019
}

\begin{abstract}
ABSTRAK
Kegiatan pengabdian ini bertujuan untuk mengevaluasi manfaat dan kendala suplementasi mineral untuk perbaikan reproduksi sapi peranakan Simmental dara yang dipelihara oleh peternak rakyat. Kegiatan diawali dengan pembuatan formula mineral komplit dengan menggunakan bahan lokal (tepung batu, kapur, dan tepung kulit kerang air tawar) sebagai komponen utama. Formula mineral lokal ini kemudian diuji kepada 24 ekor sapi peranakan Simmental darayang dipelihara 17 orang peternak selama 14 minggu dengan 4 perlakuan: P0 (tanpa suplementsi mineral, hanya diberi pakan hijauan) (kontrol), P1 (disuplementasi dengan mineral premik komersial), P2 (disuplementasi dengan mineral lokal dalam bentuk tepung), dan P3 (disuplementasi dengan mineral lokal dalam bentuk balok jilat). Sapi dibagi atas 4 kelompok sesuai dengan jumlah perlakuan, sehingga setiap perlakuan terdiri atas 6 ekor sapi sebagai ulangan dengan bobot badan berbeda. Parameter yang diukur antara lain: profil hematologi (hemoglobin ( $\mathrm{Hb}$ ), mean corpuscular $\mathrm{Hb}$ concentration (MCHC), total red blood cell(RBC), white blood cell(WBC), dan hematocrit concentration(HCT)), protein dan mineral darah (Ca, $\mathrm{P}, \mathrm{Mg})$, hormon progesteron, serta aktivitas birahi dan konsumsi pakan mineral. Suplementasi mineral berpengaruh posistif terhadap profil mineral, protein, hormone, dan hematologi darah, meskipun tidak berbeda secara statistik $(p>0,05)$. Suplementasi mineral lokal dapat menstimulir percepatan aktivitas reproduksi. Pemberian mineral lokal dalam bentuk balok jilat lebih baik daripada bentuk tepung.
\end{abstract}

Kata kunci: hematologi darah, mineral balok, pakan mineral local, suplementasi, reproduksi sapi

\begin{abstract}
This community service was aimed to evaluate beneficial effect and constrains of mineral supplementation onfeed of Simmental heifers that be raised by smallholders. Mineral were formulated by using locally available materials (rock flour, limestone, fresh water oyster shell meal) and prepared in loose and lick-block forms. The local mineral formulas were fed to 24 Simmental heifers raised by 17 smallholders for 14 weeks in four treatments: P0 (no supplementation, control), P1 (supplemented with commercial mineral premix), P2 (supplemented with local mineral feed in loose meal), and P3 (supplemented with local mineral feed in form). Each treatment consisted of 6 heifers as replication. Parameters measured included: blood minerals ( $\mathrm{Ca}, \mathrm{P}, \mathrm{Mg}$ ) and blood hematology (hemoglobin (Hb), mean corpuscular $\mathrm{Hb}$ concentration (MCHC), total red blood cell (RBC), white blood cell (WBC), hematocrit concentration (HCT)), total protein, and estrus onset. Results showed that heifers supplemented with local minerals (P2 and P3) were detected earlier estrus onset than the control (P0) and that supplemented with commercial mineral premix (P1). Local mineral supplementation gave also positive effect on blood mineral, protein and hematological profiles, even though there were no statistically difference. It was concluded that mineral supplementation gave positive effect of reproduction performances and nutritional status of Simmental heifers. Local mineral offered in lick-block had better effect than that in loose form.
\end{abstract}

Keywords: bock lick mineral, blood hematology, cattle reproduction, local mineral, supplementation 


\section{PENDAHULUAN}

Jorong atau Desa Sibaladuang terletak di lereng Gunung Sago, di Kanagarian Sungai Kamuyang, Kecamatan Luak, Kabupaten Limapuluh Kota, Provinsi Sumatera Barat. Pekerjaan utama masyarakat di desa ini adalah usaha perkebunan, seperti cokelat, kopi, pisang, dan holtikultura. Desa Sibaladuang berbatasan langsung dengan lokasi Balai Pembibitan Ternak Unggul dan Hijauan Pakan Ternak (BPTU-HPT) Padang Mangatas, yang merupakan salah satu pusat pembibitan ternak sapi potong unggul milik pemerintah. Usaha peternakan yang populer di desa ini adalah ternak sapi dan kambing. Peternak sapi di desa ini umumnya memelihara sapi jenis peranakan Simmental dengan tujuan pembibitan.

Kendala yang dihadapi peternak dalam memelihara sapi bibit tipe besar ini adalah kinerja reproduksi yang tidak sebaik sapi Simmental yang dipelihara di BPTU-HPT. Sapi induk sering mengalami masalah kesulitan bunting, terutama sapi dara dan induk setelah melahirkan anak, sehingga umur beranak pertama mencapai 30 bulan dan jarak kelahiran anak (calving interval) hampir mencapai umur 18 bulan (Suryadinata 2017). Sapi induk bahkan banyak yang mengalami kasus kemajiran setelah melahirkan anak pertama. Peternak sering tidak sabar dan terpaksa menjual sapi betina Simmental yang masih dalam masa produktif ini untuk dipotong. Masalah fertilitas dan postpartum infertility ini diduga menjadi salah satu faktor penyebab tingginya angka pemotongan sapi betina produktif di wilayah Payakumbuh. Hasil survei yang dilakukan pada tahun 2015 ditemukan bahwa jumlah sapi betina yang dipotongdi rumah potong hewan (RPH) di kota Payakumbuh mencapai 415 ekor (97\%) dari jumlah total pemotongan sebanyak 429 ekor (Reswati \& Khalil 2015), sedangkan hasil survei yang dilakukan pada tahun 2016 di lokasi yang sama menunjukkan bahwa sekitar $80 \%$ sapi betina yang dipotong adalah jenis Simmental (Khalilet al. 2016). Pemotongan sapi bibit unggul betina produktif tidak hanya akan merugikan peternak yang kehilangan kesempatan untuk mendapatkan anak sapi yang bernilai ekonomis tinggi, tetapi juga menghambat upaya pemerintah untuk mencapai swasembada daging sapi nasional.

Masalah reproduksi pada sapi bibit Simmental ini diduga terkait dengan defisiensi energi, dan zat makanan, terutama protein dan mineral, karena pakan yang diberikan peternak masih terbatas pada hijauan berupa rumput dan limbah pertanian seperti jerami padi dan sisa tanaman (stover) jagung, yang tinggi kandungan serat dan miskin zat makanan, terutama protein dan mineral (Khalil 2013; Khalil et al. 2015; Yuherman et al. 2017). Pemberian pakan konsentrat sulit dilakukan oleh peternak, karena kondisi ekonomi peternak dan keterbatasan ketersediaan bahan sumber energi dan protein. Sebaliknya, mineral dibutuhkan dalam jumlah sedikit dan dapat diproduksi dengan bahan lokal yang mudah tersedia. Mineral terkait erat dengan kesehatan dan feritilitas ternak (Suttle 2010). Ada beberapa peternak yang memberikan mineral dengan menggunakan premik komersial, tetapi hanya terbatas pada induk yang baru melahirkan anak dengan menggunakan mineral komersil. Berdasarkan hasil analisis kandungan mineral darah dan pakan hijauan yang diberikan kepada ternak, sapi bibit yang dipelihara peternak rakyat di wilayah Payakumbuh menunjukkan defisiensi beberapa jenis mineral seperti $\mathrm{Ca}, \mathrm{P}, \mathrm{Cu}$, Mn, dan Zn (Yuherman et al. 2017)

Mineral memegang peranan penting pada proses fisiologi nutrisi ternak yang terkait dengan kesehatan, pertumbuhan, reproduksi, dan sistem hormonal (Soetan et al. 2010). Beragam kasus masalah reproduksi pada sapi yang terkait dengan defisiensi mineral antara lain: gangguan perkembangan ovarium, silent heat, postpartum infertility (Kommisrud et al. 2005), prolapses, dystochia, dan kematian embrio (Chaudhary \& Singh 2004; Yasothai 2014), anestrus (Shisia et al. 2013), retained placenta, dan gangguan estrus (Yasothai 2014), hambatan rekondisi uterus setelah melahirkan dan estrus (Greene et al. 1998). Beberapa jenis mineral yang terkait dengan fungsi normal reproduksi pada sapi antara lain Mn (Shisia et al. 2013), Cu (Yasothai 2014), Zn (Yasothai 2014), Se (Smith \& Akinbamijo 2000), Ca dan P (Chaudhary \& Singh 2004; Yasothai 2014).

Kegiatan pengabdian ini bertujuan untuk mengevaluasi manfaat dan kendala pada uji coba lapang (on farm trial) suplementasi pakan mineral komplit (complete mineral feed) berbasis bahan lokal terhadap profil mineral, protein, hematologi, dan hormon reproduksi darah serta aktivitas birahi sapi Simmental dara yang dipelihara dalam skala peternakan rakyat. 


\section{METODE PELAKSANAAN KEGIATAN}

\section{Penyiapan Peternak, Ternak, dan Fasilitas Kandang}

Pelaksanaan kegiatan diawali dengan pertemuan tatap muka dengan sekitar 30 orang peternak sapi Simmental sebagai mitra untuk memberikan informasi dan diskusi tentang rencana kegiatan. Peternak tergabung dalam kelompok tani Merona yang berlokasi di Desa Sibaladuang, Kanagarian Sungai Kamuyang, Kecamatan Luak, Kabupaten Limapuluh Kota. Pertemuan dilanjutkan dengan kunjungan dan peninjauan langsung ke lokasi kandang peternak untuk memilih peternak dan menetapkan sapi yang akan digunakan, menilai kelayakan dan kebutuhan perbaikan kandang serta kesiapan peternak mitra untuk bekerja sama.

Sapi yang digunakan adalah sapi betina dara jenis Simmental sebanyak 24 ekor dengan umur berkisar antara 15-20 bulan. Sapi dipelihara oleh 17 peternak yang tersebar di 4 dusun di Desa Sibaladuang. Sapi terpilih terlebih dahulu diukur bobot badannya dengan cara mengukur panjang badan dan lingkar dada menggunakan pita ukur. Bobot badan dihitung menggunakan rumus Shaffer (McNitt 1983): W = L x G ${ }^{2} / 300$ lbs, di mana $\mathrm{W}=$ bobot badan (pound), $\mathrm{L}=$ panjang badan (inch), dan $\mathrm{G}$ = lingkar dada (inch). Bobot dalam pound dirubah menjadi kg dengan dibagi faktor 2,2. Sapi kemudian dibagi menjadi enam kelompok berdasarkan bobot badan, sehingga setiap perlakuan terdiri atas 6 ekor sapi sebagai ulangan. Sapi diberi kode pada kandang. Pada Gambar 1 disajikan kegiatan penyiapan ternak dan fasilitas kandang.

\section{Pembuatan dan Pemberian Pakan Mineral Lokal}

Formula mineral disusun dan dibuat dengan komponen utama menggunakan tiga jenis bahan mineral lokal berupa tepung batu Bukit Kamang, tepung abu kulit kerang air tawar (pensi), dan kapur. Bahan lokal ini diperkaya dikalsium fosfat, mineral mikro $\mathrm{Zn}$ dan $\mathrm{Cu}$, garam, dan premik mineral komersial (Tabel 1). Formula mineral lokal dibuat dalam dua bentuk, masing-masing berupa tepung (meal) dan balok jilat (block lick mineral feed). Penyusunan formula didasarkan pada kandungan mineral bahan pakan yang biasa diberikan peternak (Yuherman et al. 2017) dan standar kebutuhan mineral sapi menurut NRC (1996) dan standar pakan mineral suplemen menurut Weinreich et al. (1994). Kegiatan penyiapan dan pembuatan pakan mineral disajikan pada Gambar 2.

Formula mineral lokal ini kemudian diujikan melalui on farm trial selama 14 minggu, mulai 31 Mei sampai dengan September 2018. Formula diberikan kepada 24 ekor sapi dengan 4 perlakuan, yaitu P0: hanya diberi hijauan, tanpa suplementasi mineral (kontrol), P1: suplementasi dengan premik mineral komersial (50 g/ekor/hari), P2: suplementasi dengan mineral
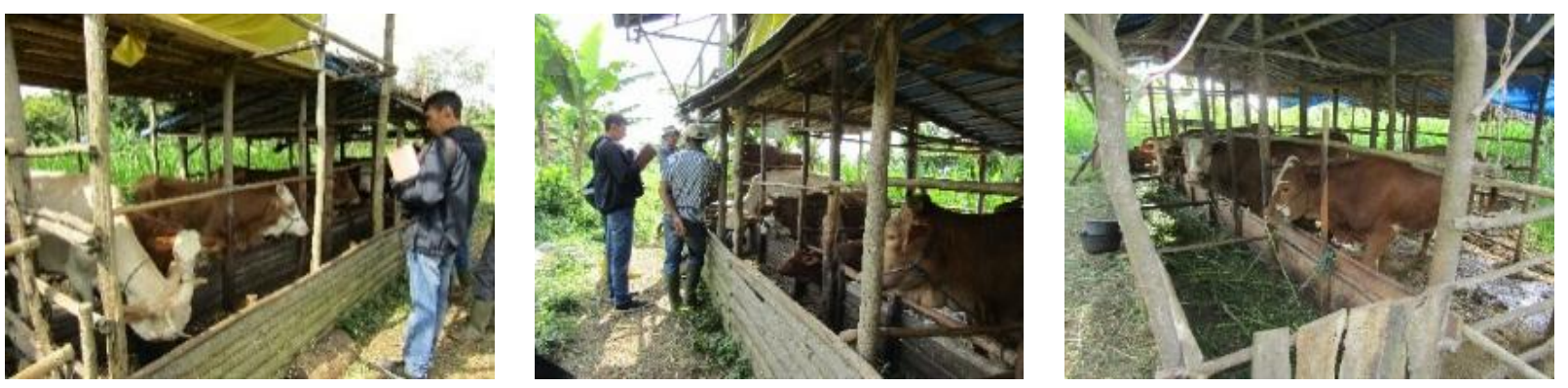

Gambar 1 kegiatan penyiapan sapi dan keadaan kandang sapi peternak yang digunakan dalam kegiatan on farm trial.

Tabel 1 Jenis dan fungsi bahan sumber yang akan digunakan dalam penyusunan formula pakan mineral berbasis bahan lokal

\begin{tabular}{|c|c|c|}
\hline Nama bahan & Fungsi sebagai sumber & Keterangan \\
\hline Tepung batu Bukit Kamang & $\mathrm{Ca}, \mathrm{Mn}, \mathrm{Fe}$ dan $\mathrm{Se}$ & \\
\hline Kapur & $\mathrm{Ca}$ & \\
\hline Tepung kulit pensi & $\mathrm{Ca}$ & \\
\hline Garam dapur (NaCl) & $\mathrm{Na}, \mathrm{I}$ & Garam beryodium \\
\hline Dikalsium fosfat & Ca dan P & \\
\hline $\mathrm{ZnSO}_{4} .7 \mathrm{H}_{2} \mathrm{O}$ & $\mathrm{Zn}$ & \\
\hline $\mathrm{CuSO}_{4} .5 \mathrm{H}_{2} \mathrm{O}$ & $\mathrm{Cu}$ & \\
\hline
\end{tabular}



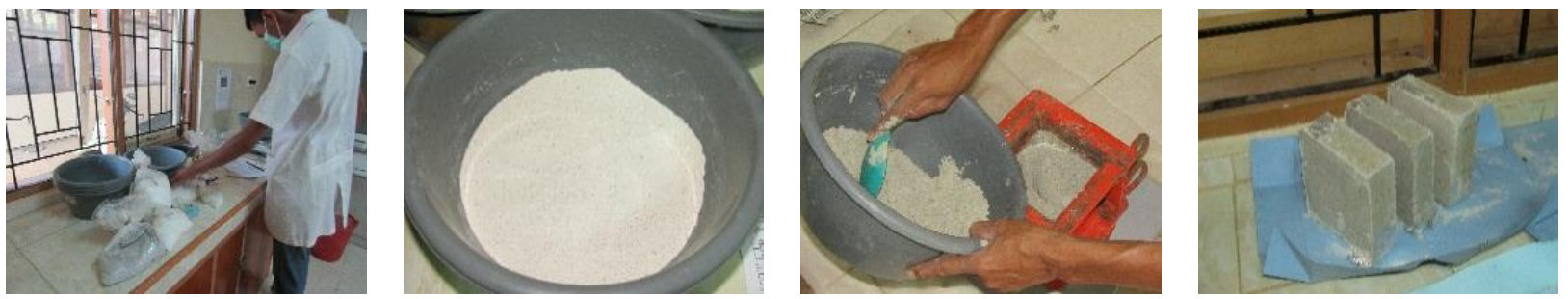

Gambar 2 Kegiatan penyiapan bahan dan pembuatan formula pakan mineral berbasis bahan lokal.

lokal bentuk tepung (100 g/ekor/hari), dan P3: suplementasi dengan mineral lokal bentuk balok, ad libitum.

Sapi dipelihara oleh 17 orang peternak. Sapi pada kelompok kontrol (P0) hanya diberi pakan hijauan berupa rumput dan limbah pertanian, sebagaimana pakan yang biasa digunakan peternak. Sapi pada kelompok perlakuan P1 selain diberi pakan hijauan, juga diberi premik mineral komersial (merek dagang UltraMineral $^{\mathrm{R}}$ ) sebanyak $50 \mathrm{~g}$ /ekor/hari, sebagaimana yang dilakukan oleh sebagian peternak. Pada perlakuan P2, selain hijauan, sapi disuplementasi dengan mineral lokal bentuk tepung, sebanyak sebanyak 100 g/ekor/hari. Pemberian mineral komersial dan mineral lokal bentuk tepung kepada sapi dilakukan dengan cara dicampur dedak padi atau dicampur dengan air minum.

Ternak yang mendapat perlakuan balok jilat (P3), balok dibuat dengan ukuran sekitar $2 \mathrm{~kg} /$ buah, kemudian ditempatkan sedemikian rupa di dekat tempat pakan dengan menggunakan block mineral box, sehingga ternak dapat mengaksesnya setiap waktu. Sapi diberi waktu untuk beradaptasi dengan perlakuan selama 15 hari, untuk memastikan bahwa sapi menyukai atau dapat mengonsumsi mineral balok dengan target sebanyak sekitar $100 \mathrm{~g} /$ ekor/hari. Setelah masa adaptasi perlakuan berakhir dan konsumsi mineral balok jilat sudah mencapai sekitar $100 \mathrm{~g} /$ ekor/hari, pengamatan dan pencatatan data selama 14 minggu, mulai tanggal 31 Mei-7 September 2018.

Selama pemberian perlakuan, sapi dipelihara dan diberi pakan sesuai dengan yang biasa dilakukan oleh peternak. Konsumsi mineral balok jilat diukur setiap minggu, di mana selisih antara berat mineral awal dengan mineral sisa merupakan konsumsi mineral oleh sapi selama satu minggu atau tujuh hari. Penggantian mineral balok dilakukan jika sudah habis selama satu minggu, jika pada satu minggu mineral balok konsumsinya sedikit maka tidak lakukan penggantian namun tetap dilakukan penimbangan. Pada Gambar 3 disajikan kegiatan pemberian mineral perlakuan.
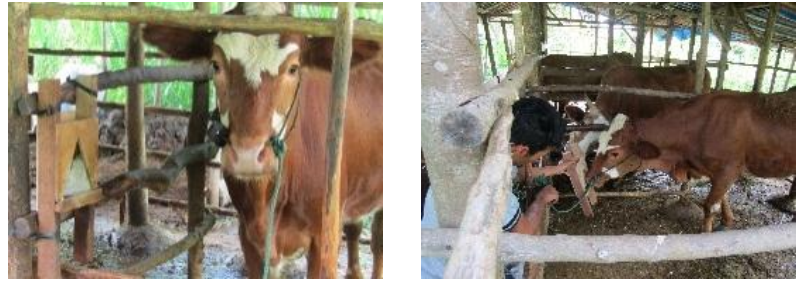

Gambar 3 Kegiatan pemasangan kotak balok jilat dan pemberian mineral perlakuan untuk sapi.

\section{Pengukuran Parameter dan Analisis Data}

Parameter yang diukur antara lain: kandungan mineral darah, hematologi darah, kandungan protein total, hormon progesteron darah, aktivitas birahi,dan konsumsi mineral balok. Parameter hematologi darah yang dianalisa antara lain: hemoglobin (HGB), mean corpuscular $\mathrm{Hb}$ concentration (MCHC), total red blood cell (RBC), white blood cell (WBC), dan hematocrit concentration (HCT). Kandungan mineral darah yang diukur antara lain: $\mathrm{Ca}, \mathrm{P}$, dan Mg.Selama on farm trial, respons peternak dan kinerja reproduksi sapi diamati. Peternak diamati kepatuhan dalam pemberian mineral. Sapi diamati tanda-tanda aktivitas reproduksi seperti estrus dan tanda-tanda lain terkait dengan pemberian mineral, seperti warna bulu, tingkah laku dan kesehatan. Tanda adanya birahi diperkuat dengan pengamatan vagina dan pengukuran suhu. Sapi yang menunjukan tanda-tanda birahi dicatat dan dikawinkan melalui pelayan inseminasi buatan.

Pengambilan sampel darah dilakukan dua kali, yaitu pada awal dan akhir minggu kegiatan. Analisa hematologi dan mineral darah dilakukan di Balai Veteriner, Baso, Bukittinggi. Analisis hematologi darah menggunakan alat Exigo spektrofotometer, sedangkan mineral dianalisis menggunakan alat spectrophotometer (Merek: Mikrolab 300 Vital-Scientific). Analisis hormon progesteron dilakukan dengan metoda RIA pada Laboratorium Terpadu IPB Bogor. Data hasil penelitian dianalisis secara statistik melalui analisis keragaman (Anova) dengan menggunakan rancangan acak kelompok, yang terdiri atas 4 perlakuan dan 6 ulangan (Steel et al. 1997). 


\section{HASIL DAN PEMBAHASAN}

Data profil hematologi, protein, mineral, dan progesteron darah serta kinerja reproduksi sapi disajikan pada Tabel 2. Semua parameter hematologi berada dalam kisaran normal, kecuali WBC. Pada sapi yang tidak diberi mineral (P0, kontrol) menunjukkan WBC di atas normal sesudah perlakuan, sedangkan pada kelompok sapi yang diberi mineral lokal bentuk tepung (P2), angka WBC di atas normal pada awal penelitian $(13,60)$, tetapi menurun menjadi normal $(12,93)$ setelah perlakuan. Pada kelompok sapi yang disuplementasi dengan mineral lokal, baik bentuk tepung (P2) maupun balok (P3) terjadi penurunan HGB, WBC, dan RBC (pada P3) setelah perlakuan, tetapi tidak berbeda secara statistik ( $p>0,05)$.Sebaliknya pada P2 terjadi peningkatan nilai HCT dan RBC. Pada sapi yang mendapat mineral lokal bentuk balok (P3) terjadi peningkatan MCHB dan total protein, tetapi secara statistik tidak berbeda nyata $(p>0,05)$.

Konsentrasi mineral Ca dan Mg darah berada dalam kisaran normal. Konsistensi kandungan mineral $\mathrm{Ca}$ dan $\mathrm{Mg}$ darah ini diduga terkait dengan adanya mekanisme homeostasis (Lean et al. 2006). Selanjutnya, konsentrasi mineral $P$ darah pada semua ternak sapi yang di- suplemenasi dengan mineral (P1, P2, dan P3) menunjukkan peningkatan dan bahkan berada di atas batas normal (3,2-6,0 mg/dL). Hal ini diduga adanya pengaruh positif dari suplementasi mineral, karena selama ini ternak kekurangan $P$. Mineral $P$ terkandung sangat rendah pada pakan hijauan, terutama yang berasal dari tanaman liar (Khalil 2013; Khalil et al. 2015; Yuherman et al. 2017). Hasil penelitian pada peternakan rakyat yang memelihara sapi bibit Simmental yang dilakukan oleh Yuherman et al. (2017) diketahui bahwa ada 4 jenis tanaman dan limbah pertanian yang dominan (dengan porsi $\geq 5 \%$ ) diberikan kepada sapi sebagai pakan hijauan, yaitu rumput gajah (Pennisetum purpureum), rumput pahit (Axonopus compressus), jerami padi, dan rumput benggala (Panicum maximum). Hijauan dominan ini mengandung mineral $\mathrm{Ca}(8-11 \mathrm{~g} / \mathrm{kg} \mathrm{BK}), \mathrm{P}$ (0,5-7,3 g/kg), dan Mn (23-29 mg/kg BK) yang lebih rendah jika dibandingkan dengan kandungan minimal di dalam ransum menurut McDowell et al. (1997) (Ca $15 \mathrm{~g} / \mathrm{kg} \mathrm{BK,} \mathrm{P} 10 \mathrm{~g} / \mathrm{kg}$ BK,dan Mn $40 \mathrm{mg} / \mathrm{kg}$ BK). Setelah dianalisis profil mineral darah diketahui bahwa sapi bibit yang dipelihara peternak di wilayah Payakumbuh menunjukkan defisiensi mineral $\mathrm{Ca}$, $\mathrm{P}, \mathrm{Cu}, \mathrm{Mn}$, dan Zn (Yuherman et al. 2017). Selanjutnya, hasil penelitian yang dilakukan Khalil

Tabel 2 Profil hematologi, mineral, protein, dan hormon progesteron darah serta aktivitas birahi sapi Simmental dara yang disuplmentasi dengan mineral lokal

\begin{tabular}{|c|c|c|c|c|c|c|c|c|c|}
\hline \multirow[t]{2}{*}{ Parameter } & \multicolumn{2}{|c|}{$\begin{array}{c}\text { Kontrol } \\
\text { (hanya diberi hijauan) } \\
\text { (P0) }\end{array}$} & \multicolumn{2}{|c|}{$\begin{array}{l}\text { Suplementasi dengan } \\
\text { premik mkneral } \\
\text { komersial (P1) }\end{array}$} & \multicolumn{2}{|c|}{$\begin{array}{l}\text { Suplementasi dengan } \\
\text { mineral lokal bentuk } \\
\text { tepung (P2) }\end{array}$} & \multicolumn{2}{|c|}{$\begin{array}{c}\text { Suplementasi dengan } \\
\text { mineral lokal bentuk } \\
\text { balok (P3) }\end{array}$} & \multirow[t]{2}{*}{$\begin{array}{c}\text { Kisaran } \\
\text { normal }\end{array}$} \\
\hline & Sebelum & Sesudah & Sebelum & Sesudah & Sebelum & Sesudah & Sebelum & Sesudah & \\
\hline \multicolumn{10}{|l|}{ Hematologi:* } \\
\hline \multirow[t]{2}{*}{$\mathrm{HGB}(\mathrm{g} / \mathrm{dL})$} & $8,60 \pm$ & $9,62 \pm$ & $8,75 \pm$ & $10,12 \pm$ & $10,22 \pm$ & $9,45 \pm$ & $9,40 \pm$ & $8,92 \pm$ & $8,40-12,00$ \\
\hline & 1,53 & 1,84 & 1,34 & 2,17 & 4,06 & 1,65 & 1,56 & 1,08 & \\
\hline \multirow[t]{2}{*}{$\mathrm{MCHb}(\mathrm{g} / \mathrm{dL})$} & $42,23 \pm$ & $41,52 \pm$ & $41,90 \pm$ & $40,78 \pm$ & $41,43 \pm$ & $41,23 \pm$ & $41,25 \pm$ & $42,03 \pm$ & $38,00-43,00$ \\
\hline & 0,91 & 1,20 & 1,04 & 1,15 & 1,21 & 1,02 & 1,29 & 1,67 & \\
\hline \multirow[t]{2}{*}{ HCT (\%) } & $20,47 \pm$ & $23,27 \pm$ & $20,98 \pm$ & $24,95 \pm$ & $20,73 \pm$ & $23,05 \pm$ & $22,92 \pm$ & $21,27 \pm$ & $21,00-30,00$ \\
\hline & 3,92 & 4,91 & 3,73 & 5,69 & 3,48 & 4,46 & 4,23 & 2,89 & \\
\hline \multirow[t]{2}{*}{$\mathrm{RBC}\left(\mathrm{x} 10^{6} / \mu \mathrm{L}\right)$} & $5,20 \pm$ & $5,86 \pm$ & $5,76 \pm$ & $6,26 \pm$ & $5,40 \pm$ & $5,57 \pm$ & $6,10 \pm$ & $5,47 \pm$ & $4,90-7,50$ \\
\hline & 1,36 & 1,41 & 0,81 & 1,21 & 0,86 & 0,86 & 1,08 & 0,78 & \\
\hline \multirow[t]{2}{*}{ WBC $\left({ }^{x} 10^{6} / \mu \mathrm{L}\right)$} & $10,63 \pm$ & $13,57 \pm$ & $13,25 \pm$ & $11,00 \pm$ & $13,60 \pm$ & $12,93 \pm$ & $12,87 \pm$ & $11,60 \pm$ & $5,10-13,30$ \\
\hline & 1,97 & 3,51 & 4,11 & 4,94 & 1,52 & 4,19 & 2,57 & 2,57 & \\
\hline \multirow{2}{*}{$\begin{array}{l}\text { Total protein } \\
(\mathrm{mg} / \mathrm{dL})\end{array}$} & $6,40 \pm$ & $6,53 \pm$ & $5,97 \pm$ & $7,07 \pm$ & $6,75 \pm$ & $7,77 \pm$ & $6,05 \pm$ & $6,98 \pm$ & \\
\hline & 1,02 & 1,31 & 0,47 & 2,84 & 0,87 & 3,06 & 1,22 & 2,12 & 6,50-8,50 \\
\hline \multicolumn{10}{|l|}{ Mineral (mg/dL)** } \\
\hline \multirow[t]{2}{*}{$\mathrm{Ca}$} & $10,17 \pm$ & $10,67 \pm$ & $10,08 \pm$ & $11,07 \pm$ & $12,00 \pm$ & $10,68 \pm$ & $10,62 \pm$ & $10,48 \pm$ & $8,50-11,50$ \\
\hline & 0,99 & 2,41 & 1,67 & 4,36 & 1,94 & 2,98 & 2,93 & 3,31 & \\
\hline \multirow[t]{2}{*}{$\mathrm{Mg}$} & $3,50 \pm$ & $3,50 \pm$ & $3,18 \pm$ & $2,65 \pm$ & $3,23 \pm$ & $3,05 \pm$ & $3,28 \pm$ & $3,10 \pm$ & $1,80-3,20$ \\
\hline & 0,64 & 0,77 & 0,41 & 0,46 & 1,08 & 0,68 & 0,97 & 0,74 & \\
\hline \multirow[t]{2}{*}{$\mathrm{P}$} & $6,47 \pm$ & $5,50 \pm$ & $4,28 \pm$ & $7,33 \pm$ & $4,83 \pm$ & $7,38 \pm$ & $5,20 \pm$ & $8,57 \pm$ & $3,20-6,00$ \\
\hline & 1,06 & 1,16 & 0,92 & 1,58 & 0,92 & 1,12 & 0,95 & 3,44 & \\
\hline Hormon & $1,30 \pm$ & $1,40 \pm$ & $1,27 \pm$ & $2,10 \pm$ & $1,20 \pm$ & $3,20 \pm$ & $1,39 \pm$ & $2,60 \pm$ & \\
\hline $\begin{array}{l}\text { progesteron } \\
\text { (ng/mL) }\end{array}$ & 0,59 & 0,82 & 0,17 & 1,69 & 0,00 & 3,84 & 0,29 & 3,43 & \\
\hline $\begin{array}{l}\text { Jumlah sapi } \\
\text { birahi (ekor) }\end{array}$ & \multicolumn{2}{|c|}{$4(66,7 \%)$} & \multicolumn{2}{|c|}{$4(66,7 \%)$} & \multicolumn{2}{|c|}{$3(50 \%)$} & \multicolumn{2}{|c|}{$4(66,7 \%)$} & \\
\hline
\end{tabular}

Keterangan: *) kisaran normal menurut Wood \& Quiroz-Rocha (2010); dan ${ }^{* *}$ ) kisaran normal menurut McDowell (1997) 
et al. (2016) di BPTU-HPT Padang Mangatas menunjukkan bahwa beberapa jenis mineral yang terkait dengan reproduksi, seperti $\mathrm{Mn}, \mathrm{Se}$, $\mathrm{Cu}$, dan $\mathrm{Zn}$ ditemukan defisien pada sampel darah sapi, tanah, dan pakan hijauan yang ditanam di lahan padang penggembalaan.

Sebagaimana terlihat pada Tabel 5 secara total ada 15 ekor sapi dari jumlah total 24 ekor yang menunjukkan aktivitas birahi selama 14 minggu pengamatan, dengan rincian 4 ekor $(66,7 \%)$ pada P0 (kontrol), 4 ekor $(66,7 \%)$ pada P1 (mineral premix komersial), 3 ekor $(50 \%)$ pada P2 (mineral lokal bentuk tepung) dan 4 ekor (66,7\%) pada P3 (mineral lokal bentuk balok jilat). Meskipun jumlah sapi yang birahi tidak lebih banyak daripada sapi pada perlakuan kontrol (P0) dan mineral premik komersial (P1), sapi dara yang disuplementasi dengan formula mineral lokal (P2 dan P3) sudah menunjukkan tanda-tanda birahi pada minggu ke-2 pada bulan pertama dan minggu pertama bulan kedua, sedangkan pada sapi kelompok kontrol (P0) dan premik mineral komersial (P1), tanda birahi baru muncul pada minggu pertama bulan ke-4. Pengaruh positif terhadap perbaikan reproduksi ini ditunjang data hematologi darah dan didukung dengan terja-dinya kenaikan konsentrasi hormon progesteron pada kelompok sapi yang diberikan pakan mineral lokal (P2 dan P3, pada Tabel 5). Sapi yang diberi mineral lokal dalam bentuk balok jilat (P3) menunjukkan aktivitas reproduksi yang lebih baik, baik dari segi jumlah sapi maupun waktu awal munculnya tanda-tanda birahi, daripada kelompok sapi yang diberi mineral lokal bentuk tepung (P2). Perbaikan reproduksi ini diduga terkait dengan pola konsumsi. Mineral bentuk balok dikonsumsi dengan cara dijilat secara perlahan-lahan, sehingga suplai mineral pada ternak berlangsung secara kontinu selama 24 jam. Temuan ini ditunjang oleh hasil penelitian terdahulu,dimana sapi Simmental dara yang diberi suplemen mineral lokal dalam bentuk balok jilat dengan komponen utama tepung batu Bukit Kamang dan tepung kulit pensi, me-nujukkan pertambahan bobot badan, konversi ransum, dan penerimaan yang nyata $(\mathrm{P}<0,05)$ lebih baik daripada yang hanya diberi rumput dan kosentrat (Khalil et al. 2015).

Kendala yang dihadapi dalam pemberian mineral ini adalah kepatuhan peternak untuk memberikannya setiap hari pada sapi. Peternak yang sapinya mendapat perlakuan mineral bentuk tepung terutama P2, sering tidak patuh memberikan mineral pada sapi. Kendala lainnya, peternak yang sapinya mendapat perlakuan mineral lokal bentuk balok jilat (P3) sering tidak menyediakan air minum untuk sapi-sapi, sehingga sapi tidak dapat mengonsumsi mineral secara optimal. Sapi sering kekurangan minum. Kondisi ini diperparah dengan datangnya musim kering di lokasi petani, sehingga suhu udara meningkat dan ketersediaan air untuk minum sapi semakin terbatas. Garam yang terkandung pada formula mineral lokal sekitar 20\% menghambat konsumsi, jika ketersediaan air minum terbatas dan tidak ad libitum. Pada Gambar 4 terlihat bahwa rataan konsumsi mineral balok menurun dari 68 g pada minggu pertama menjadi hanya $20 \mathrm{~g} /$ ekor/hari pada minggu ke-14. Rataan konsumsi balok jilat hanya 38,9 g/ekor/hari, jauh di bawah target konsumsi yang diharapkan, yaitu $100 \mathrm{~g} /$ ekor/hari.

Usaha peternakan sapi rakyat di desa Sibaladuang perlu didukung untuk dapat menghasilkan bibit sapi potong unggul, dalam upaya

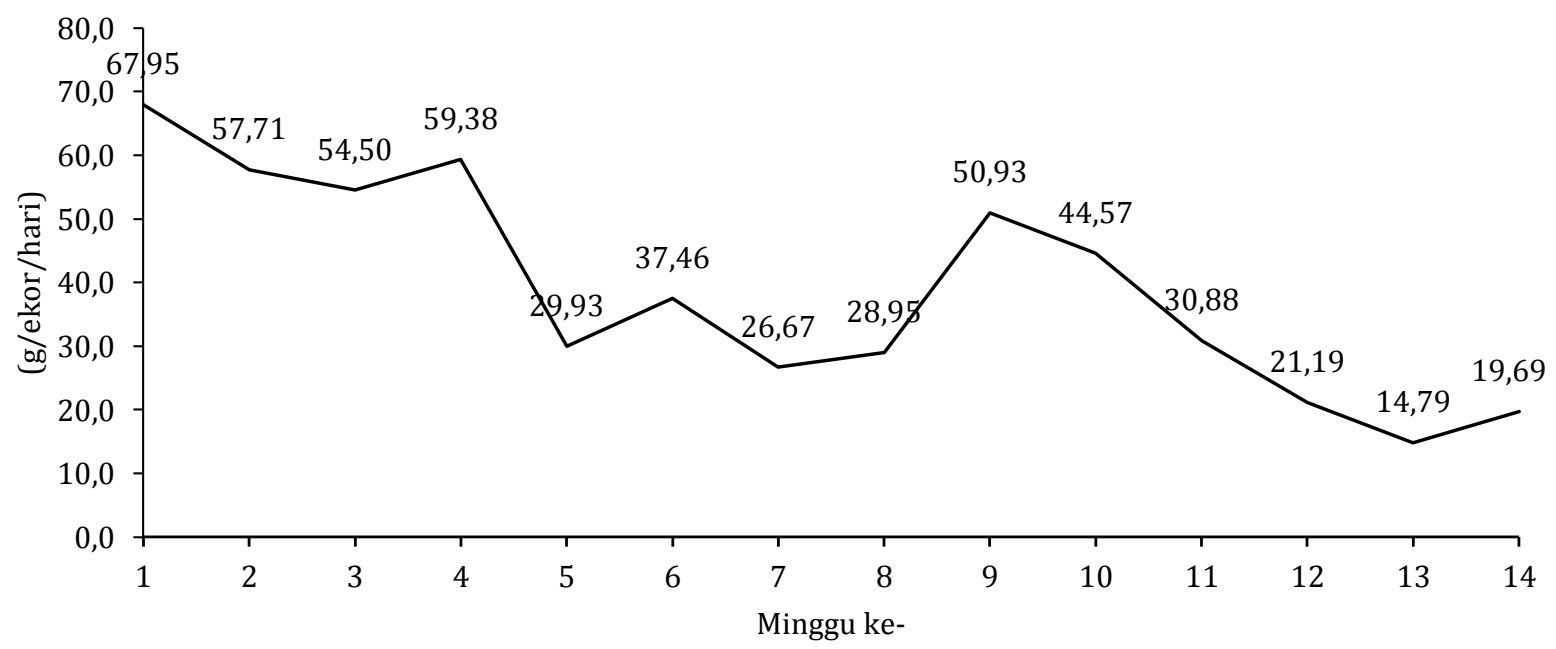

Gambar 4 Perkembangan konsumsi mineral balok selama 14 minggu. 
menunjang program pemerintah untuk mencapai swasembada daging nasional dan menciptakan lapangan pekerjaan di daerah pedesaan, sehingga usaha dapat berlanjut dan berkembang dan kebutuhan masyarakat akan sapi dapat terpenuhi. Pemenuhan kebutuhan mineral melalui pakan suplemen dengan memanfaatkan bahan lokal diharapkan dapat dijadikan salah satu cara yang paling murah dan praktis untuk mengatasi masalah reproduksi sapi bibit impor tipe pedaging dengan sistem pemeliharaan dan kualitas pakan yang terbatas.

\section{SIMPULAN}

Suplementasi mineral berpengaruh posistif terhadap status nutrisi dan yang tercermin dari perbaikan profil hematologi, mineral, dan hormon reproduksi darah. Suplementasi mineral lokal juga dapat menstimulir poduksi hormon reproduksi dan percepatan aktivitas birahi sapi Simmental dara. Pemberian mineral lokal dalam bentuk balok jilat memberikan pengaruh lebih baik daripada bentuk tepung. Kurangnya pengetahuan dan kesadaran peternak tentang pentingnya mineral untuk reproduksi dan keterbatasan ketersediaan air minum menjadi faktor kendala dalam upaya perbaikan nutrisi dan reproduksi sapi bibit unggul tipe besar yang dipelihara oleh peterakan rakyat.

\section{UCAPAN TERIMA KASIH}

Kegiatan on farm trial ini merupakan bagian dari pelaksanaan proyek Penelitian Berbasis Kompetensi dibiayai oleh Direktorat Jenderal Penguatan Riset dan Pengembangan Kementerian Riset, Teknologi dan Perguruan Tinggi sesuai dengan Kontrak Penelitian No. 050/SP2H/LT/ DRPM/2018.

\section{DAFTAR PUSTAKA}

Chaudhary S, Singh A. 2004. Role of nutrition in reproduction: a review. Intas Polivet. 5(2): 229-234. https://doi.org/10.1016/j.sram. 2004.11.004

Greene LW, Johnson AB, Paterson JA, Ansotegui RP. 1998. Role of trace minerals in cow-calf cycle examined. Feedstuffs. 70: 12-17.
Khalil. 2013. Evaluation of availability and quality of forages at Limau Manis Campus, Andalas University, Padang, West Sumatra. In: Prociding The $3^{\text {rd }}$ AINI Internatonal. September 24-25. Padang (ID) West Sumatra.

Khalil, Lestari MN, Sardilla P, Hermon. 2015. The use of local mineral formulas as a feed block supplement for beef cattle fed on wild forages.Media Peternakan. 38(1): 34-41. https://doi.org/10.5398/medpet.2015.38.1.3 4

Khalil, Reswati, Fitri YK, Indahwati, Yuherman. 2016. Seasonal forage availability, nutrient composition and mineral concentration of imported breed cattle at the Padang Mangatas Breeding Center for Beef Cattle in West Sumatra, Indonesia. Pakistan Journal of Nutrition. 15(12): 1034-1041. https:// doi.org/10.3923/ jn.2016.1034.1041

Kommisrud E, Østerås 0, Vatn T. 2005. Blood selenium associated with health and fertility in Norwegian dairy herds. Acta Veterinaria Scandinavica. 46 (4): 229-240. https:// doi.org/10.1186/1751-0147-46-229

Lean IJ, DeGaris PJ, McNeil DM, Block E. 2006. Hypocalcaemia in dairy cows: meta-analysis and dietary cation anion difference theory revisited. Journal of Dairy Science. 89: 669-684. $\quad$ https://doi.org/10.3168/jds. S0022-0302(06)72130-0

McDowell LR. 1997. Minerals for Grazing Ruminants in Tropical Regions. 3rd edition. Gainesville (US): University of Florida.

McNitt JI. 1983. Livestock Husbandry Techniques. London (UK): Granada Publishing Ltd.

NRC. 1996. Nutrient Requirment of Beef Cattle: Seventh Rivised Edition: Update 2000. Washington, D.C (US): The National Academy Press,.

Reswati, Khalil. 2015. Performa sapi siap potong di rumah potong hewan Payakumbuh. Dalam: Prosiding Seminar Nasional: Ketahanan pangan dan pertanian berkelanjutan: peluang dan tantangan implementasi teknologi dalam perspektif nasional. Polteknik Pertanian Negeri Payakumbuh. Payakumbuh (ID), Oktober 2015. 
Shisia KS, Ngure V, Nyambaka H,Oduor FDO. 2013. Effect of $\mathrm{pH}$ and forage species on mineral concentrations in cattle breeds in major grazing areas of Uasin Gishu County, Kenya. International Journal of Current Microbiologi and Applied Sciences. 2(12): 247-254.

Smith OB, Akinbamijo 00. 2000. Micronutrients and reproduction in farm animals. Animal Reproduction Science.2(60-61): 549-560. https://doi.org/10.1016/S0378-4320(00) 00114-7

Soetan KO, Olaiya CO, Oyewole OE. 2010. The importance of mineral elements for humans, domestic animals and plants: A review. African Journal of Food Science. 4(5): 200-222.

Steel RGD, Torrie JH, Dickey DA. 1997. Principles and Procedures of Statistics: A Biometritrical Approach. $3^{\text {rd }}$ Edition. New York (USA): McGraw-Hill Book Co. Inc.

Suryadinata A. 2017. Analisis Kandungan Mineral Hijauan dan Darah Dikaitkan dengan Performa Reproduksi Sapi Simmental di
Wilayah Payakumbuh (2017). [Skripsi]. Fakultas Peternakan Universitas Andalas.

Suttle NF. 2010. Mineral Nutrition of Livestock. $4^{\text {th }}$ Ed. Moredun Foundation. Midlothian (UK): Pentland Science Park.

Weinreich O, Koch V, Knippel J. 1994. Futtermittelrechtliche Vorschriften. Frankfurt (DE): Agrimedia. Pp.166-167.

Wood D, Quiroz-Rocha GF. 2010. Normal hematology of cattle. In: Schalm's veterinary hematology, ed. Weiss DJ, Wardrop KJ, 6th ed., pp. 829-835. Wiley, Ames, IA.

Yasothai Y. 2014. Importance of minerals on reproduction in dairy cattle. International Journal of Science, Environment and Technology. 3(6): 2051-2057.

Yuherman, Reswati, Yulianti Fitri Kurnia, Indahwati, Khalil, 2017. Hematological and mineral profiles of reproductive failure of exotic breed cattle in Payakumbuh, West Sumatra, Indonesia. Pakistan Journal of Nutrition. 20: 390-396. https:// doi.org/10.3923/pjbs.2017.390.396 